\title{
ВЛИЯНИЕ СИНТЕТИЧЕСКИХ СТЕРОИДОВ НА ЭКСПРЕССИЮ МРНК БЕЛКОВ ЛЕКАРСТВЕННОЙ УСТОЙЧИВОСТИ В КЛЕТКАХ НЕLА И МСF-7, РЕЗИСТЕНТНЫХ К ДОКСОРУБИЦИНУ
}

\author{
О.Ю. Земляная, Д.Д. Есипова, Э.Э. Варпетян \\ НИЛ молекулярной фармакологии, ФГАОУ ВО РНИМУ им. Н.И. Пирогова \\ Минздрава России, 119435, Россия, г. Москва, ул. Б.Пироговская, д. 9 А.
}

DOI: 10.19163/MedChemRussia2021-2021-483

E-mail: science55569@mail.ru

Новые производные 17-ацетата мепрегенола, содержащие модифицированную гидроксильную группу в 3-м положении прегнанового каркаса, синтезированы вкачестве кандидатов в противоопухолевые средства как описано в [1]. Ранее было установлено, что как вновь синтезированные стероиды, так и их структурные аналоги - прогестерон, МПА и мегестрола ацетат обладают цитотоксическим действием на опухолевые клетки человека линии Hela и MCF-7 с IC ${ }_{50}$ в диапазоне 5-100 мкM и слабым цитотоксическим действием на фибробласты кожи крыс. Также известно, что прегнановые стероиды являются модуляторами МДР [1]. Целью данной работы стала оценка действия прегнановых стероидов на экспрессию мРНК белков множественной лекарственной устойчивости MRP1, MDR, BCL-2 в опухолевых клетках HeLa и MCF-7, резистентных к доксорубицину.

Прегнановые стероиды 314, 317, 321, а также гестобутаноил и МПА в концентрации 10 мкМ инкубировали с клетками в течение 48 ч, оценку экспрессии генов оценивали методом REAL-TIME ПЦР.

B клетках HeLaпрегнановые стероиды незначительно увеличивают экспрессию BCL-2 за исключением соединения 317 (снижает экспрессию в 1,6 раз). MA максимально увеличивает BCL-2 в 22 раза. B клетках MCF-7 все стероиды уменьшают экспрессию $\mathrm{BCL}$, кроме гестобутаноила (увеличивает в 128 раз). Экспрессия мPHK MRP снижалась в клетках HeLa под действием 317 и гестобутаноила (в 16 и 3 раза соответственно), остальные стероиды стимулировали синтез мРНК. В клетках MCF-7 стероиды увеличивали синтез мРНК на 40-70\%, кроме соединения 321 (снижал в 2,5 раза). Из ряда изученных стероидов соединение 317, содержащее в своей структуре молекулу брома, в набольшей степени снижает экспрессию белков МЛУ в обеих культурах.

Работа выполнена при поддержке гранта РФФИ №19-015-00195а.

\section{Литература}

1. Fedotcheva T.A., Sveshnikova E.D., Sheina N. letal. Synthesis and cytostatic activity of new derivatives of mepregenol 17-acetate with respect to HeLa cancer cells. Pharmaceutical Chemistry Journal, 2020; 54(2): 119-125, doi10.1007/s11094-020-02167-1. 